\title{
Az abszolút és relacionális térszemlélet közötti hamis dichotómia
}

\section{The false dichotomy between the concepts of absolute and relational space}

\author{
DUSEK TAMÁS
}

A két filozófiai térszemlélet, az abszolút és a relacionális tér koncepcióját a különféle térelméleti és regionális gazdaságtani munkák, Faragó László tanulmányához hasonlóan (Faragó 2012), gyakran ismertetik. Ezeknek az ismertetéseknek véleményem szerint négy támadható pontjuk lehet:

1. Eltúlozhatják a két koncepció közötti különbséget, ami inkább a formális részekben, a hangsúlyokban, szóhasználatban mutatkozik meg, semmint tényleges érdemi eltérést jelentene.

2. Előfordulhat, hogy olyan dichotómiaként tekintenek a két közelítésre, hogy vagy az egyiknek, vagy a másiknak van igaza, a kettő egyszerre nem lehet érvényes.

3. Az abszolút teret tudományosan meghaladottnak tarthatják, a relacionális teret a relativitáselmélet által bizonyítottan tudományosnak és modernnek tekintik.

4. Nem foglalkoznak azzal, hogy van-e gyakorlati következménye a két térszemléletnek egyáltalán bármire, különösen a regionális gazdasági elméletek építésére vagy a regionális politikára vonatkozóan.

Ez a négy pont a lehetséges hiányosságokat jelenti, és nem azt, hogy minden egyes ismertetést ez jellemezné. Az is előfordulhat, hogy így együtt sehol sem található meg a négy pont. Faragó László tanulmánya például foglalkozik a negyedik ponttal és tárgyalja a térszemlélet gyakorlati jelentőségét. Nem célom azonban a különféle ismertetéseket abból a szempontból osztályozni, hogy a fenti pontokban melyik hogyan foglal állást. Ehelyett rövid hozzászólásomnak két egymással összefüggő célja van. Egyrészt a fenti gyengeségek tartalmát szeretném kifejteni. Másrészt annak a megközelítésnek a veszélyeivel kívánok foglalkozni, amely szerint „e fogalmak [tér, terület, régió, hely stb.] kifejtésére, rendszerezésére azért is szükség van, mert általában megvan az igény a közös szakmai nyelvre, úgy érezzük, hogy szükség van rá ahhoz, hogy értsük egymást, hogy hatékonyan tudjunk kommunikálni” (Faragó 2012, 6. o.).

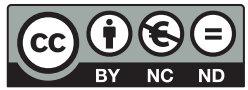




\section{Az abszolút és relacionális térkoncepció hasonlósága}

Az abszolút (anyagi) értelmezés szerint a tér önállóan létező tárgy a többi tárgy mellett. A relacionális (relatív, kapcsolati) értelmezés alapján a tér a tárgyak közötti viszonyként értelmezett. A két koncepció azért hasonló, mert a helyzetmeghatározás során az abszolút nem nélkülözheti a relativitás eszméjét, a relacionális az abszolút módú rögzítettséget. Az abszolút értelmezésben benne van a relativitás, akár az abszolút tér különböző pontjaiként értelmezett viszonyként, akár ebben az abszolút térben lévő tárgyak közötti viszonyként. A relatív értelmezésben pedig az abszolút elem jelentkezik: bármely pontot viszonyítási alapnak kijelölve létrehozható egy abszolút koordináta-rendszer, amire szükség is van a helyzetmeghatározáshoz. A két térkoncepció lényegét tekintve azonos. A tér egyszerre abszolút és relatív is, és nem egyik vagy másik. A hangsúlybeli különbség úgy jelentkezik, hogy az abszolút térkoncepciónál a dolgok mögé még odaképzeljük a teret mint önálló dolgot, a relatívban pedig nem. A két értelmezés jól megfér egymás mellett, egyik sem zárja ki a másikat. Metafizikai vitát természetesen lehet róluk folytatni, de annak sok értelme nincs.

Faragó László azt írja, hogy „a hagyományos abszolút térszemléletet a filozófia már jóval Einstein és Minkowski előtt meghaladta. Már Newton kortársa, Leibniz kifejtette - ezzel megteremtve a modern térfelfogást -, hogy a tárgyak helyzete a többi tárgyhoz való relatív viszonyában értelmezhetö" (Faragó 2012, 10. o.). Ez a megközelítés nem egyedi, de az elmondottakból következően nem értek egyet a két térkoncepció dichotomikus szembeállításával sem, azzal pedig még kevésbé, hogy az egyik a másikat meghaladhatja. Nemcsak a tárgyakra, hanem a tér mindegyik pontjára is igaz az, hogy „,helyzete a többi tárgyhoz való relatív viszonyában értelmezheto"”.

A két térkoncepció dichotomikusan különbözőnek tekintett voltából ugyanakkor még nem feltétlenül következik az a vagylagos megközelítés, hogy vagy az egyik, vagy a másik félnek van igaza. Lehetséges az is, hogy a két koncepciót eltérő körülmények között tekintik érvényesnek. A zavart egyrészt az okozza, hogy a kérdésbe belekeverik a mozgást és a mechanika (fizika) térkezelését. Másrészt a következő érveléssel is lehet találkozni. Az abszolút térszemlélet rögzített koordináta-rendszerében egy tárgy helyzetét nem befolyásolja az, hogy a rendszerhez hozzáadunk vagy elveszünk egy másik tárgyat. A relacionális térszemlélet alapján viszont, mivel eszerint a tér a tárgyak közötti viszony, egy tárgy elvétele vagy hozzáadása megváltoztatja minden tárgynak a relatív helyzetét. (Ilyen „hozzáadott és elvett” tárgyak lehetnek például a közlekedéshálózat vizsgálatakor az útszakaszok, egy új útszakasz vagy egy útszakasz felszámolása; a településhálózatnál egy új település vagy egy elnéptelenedett korábbi település, de a népességszám változása is.) Ezért a térbeli kapcsolatokkal foglalkozók számára a relacionális térszemlélet a megfelelő (Gatrell 1979, 508. o.). Ezt az érvelést félreértésen alapulónak tartom. A tárgy helyzete egy 
másik tárgy elvételével vagy hozzáadásával az első esetben (abszolút térszemlélet) is csak a koordináta-rendszerhez képest nem változik, egyébként a tárgyak összességéhez képest ugyanaz a változás következik be, mint a relatív térszemlélet szerint. Az utóbbiban pedig a koordináta-rendszer helyzete nem változik, ha egyes objektumokat elveszünk vagy hozzáadunk, mert a koordináta-rendszer helyzetét bármely ponthoz képest meg lehet határozni.

Egy példával élve, az euklidészi geometriát fel lehet fogni úgy, mint amely magának a két- vagy háromdimenziós térnek a vizsgálatával foglalkozik, és amelyre így az abszolút térszemlélet jellemző. De lehet azt is mondani, hogy az euklidészi geometria a „merev testek kölcsönös helyzete lehetőségeinek tana” (Einstein 1971, 217. o.), vagyis amelyre a relacionális térszemlélet jellemző. Pontosabban az abszolút és a relacionális térszemlélet egyszerre. Egy kör definíciójában vagy bármely tételben a pontok és más mértani objektumok közötti kölcsönös (relatív) viszonyra vonatkozó állításoknak szükségszerüen meg kell jelenniük, ennek hiányában az egész geometria értelmezhetetlen lenne.

Faragó László szerint az abszolút térszemlélet jellemző a klasszikus regionális gazdaságtanra, a telephelyelméletekre. A relacionális térszemlélet alapján pedig nem a NUTS típusú régiók, hanem a funkcionális és a csomóponti régiók kialakítása szorgalmazható. Véleményem szerint a régiók kialakítása nem a térszemlélettől, hanem a regionalizálás céljától függ. Területi statisztikai célú lehatárolásnál például (NUTS) nem indokolt az, hogy a területegységek között átfedések vagy hézagok, lefedetlen területek legyenek. A közszolgáltatásoknál pedig, például a földhivatalok területi szervezeténél területileg nem hatékony az sem, ha egy országban egyetlen földhivatal van, és az sem, ha ellátatlan területek vagy átfedések vannak az egyes területi földhivatalok között. A csomóponti régió kialakítása tehát nem szorgalmazható olyankor, amikor egyértelmü határok megvonására van szükség. De ez nem a térszemléletből következik, hanem ésszerü gyakorlati követelményként jelentkezik.

\section{A térfogalom tisztázási szándéka problémája}

Faragó László azzal a nézettel legitimálja tanulmányának tárgyát, ami szerint az értelmes tudományos párbeszéd előfeltételként követeli meg a fogalmak tisztázását. Ezt a népszerű nézetet csak annyiban osztom, ha a fogalmak tisztázása a pragmatikusan szükséges minimális szintre szorítkozik, ha megvan a törekvés a világos, következetes nyelvhasználatra, ha egy konkrét helyzetben egyértelmüsíti a szerző egy bizonytalannak ítélhető vagy több jelentéssel bíró fogalom kapcsán, hogy mit ért rajta, és ha adott szövegen belül nem változtatgatják önkényesen a terminusok jelentését. A szavak legnagyobb része azonban nem definiálandó, mert a szövegkörnyezetből nyeri jelentését, és ez különösen igaz az olyan gyakran és számos eltérő helyzetben használt szavakra, mint a tér, régió, hely. Az ál- 
talános fogalmak olyan típusú meghatározásának, hogy „Mi a tér?”, „Mi a régió?” stb. nincsen szerepe a tudományban. A definiálási igény következményeként jöttek létre többek között olyan mesterségesen elkülönített kategóriák és hamis dichotómiák is, mint amit az abszolút-relacionális mint állítólag egymást kizáró térszemlélet példájában láthattunk. Másrészt az ilyen fogalmak definiálási kísérletei oda vezettek, hogy vagy egy egyszerü, érthető, definiálásra nem szoruló alapfogalomnak egy specializált helyzetekben érvényes, leszükítő jelentést adtak, vagy posztmodern homályosságokkal helyettesítették. Tudományos definíciók megadására egy tudományos problémaszituáció során, a nyelvhasználat egyszerüsítése érdekében kerülhet sor.

Az általános definiálási kísérletek szükségtelenségének, sőt káros voltának az okát Popper nagyon világosan mutatja be. Szerinte a fogalmak meghatározásának kétféle módszerét különböztethetjük meg: egyik esetben egy hosszabb meghatározást helyettesítünk egy specializált jelentésủ rövidebbel, a másik esetben egy általános jelentésű rövid fogalmat helyettesítünk egy hosszabbal. Az előbbi eljárás egyszerűsíti a nyelvhasználatot, az utóbbi bonyolítja. Az előbbivel vezették be az ökológiai korreláció, a módosítható területi egység problémája, az anyagindex, a telephelysúly, a FOB ár, a központi helyek elmélete és sok más hasonló szakterminust. Anélkül, hogy mindig le kellene írni azt a hosszú meghatározást, amit ezek a fogalmak jelentenek, mindezt egy rövidebb címkével lehet helyettesíteni. A fenti fogalmak jelentésében nincs nézeteltérés, legfeljebb előfordulhat, hogy valaki nem találkozott még velük, és ezért nem tudja, mit jelentenek. A fogalmak definiálási igénye Popper szerint szavakon rágódó, üres skolaszticizmust, homályos szócséplést eredményez. ${ }^{1}$ Szavak meghatározásához más szavakra van szükség, a meghatározásban részt vevő szavakat ismét meg kellene határozni, és így tovább a végtelenségig. A nyelvhasználat pontosítási kísérlete a céljával ellentétes eredményre vezet: áttekinthetetlenül bonyolulttá, terjengőssé teszi a nyelvet. „Egy nyelv pontossága éppen azon múlik, hogy gondosan ügyel rá, ne terhelje meg fogalmait azzal a feladattal, hogy pontosak legyenek" (Popper 2001, 215-216. o.). Popperrel megegyezően vélekedik a kérdésről Kaplan: „A jelentés egzaktsága és a terminusok precíz definíciója iránti igénynek könnyen káros hatása lehet, ahogyan azt hiszem ez a viselkedési tudományokban gyakran meg is történik. A tudományon kívüli dogmatizmus támogatja a jelentés zárt rendszereit; a tudós nem sürgeti a jelentés lezárását. A kétértelműség iránti tolerancia a tudományos kreativitás számára ugyanolyan fontos, mint bárhol máshol" (Kaplan 1964, 70-71. o.).

\section{Jegyzet}

1 Popper kifejezései az érvelése szövegkörnyezetéből kiszakítva élesek és nem diplomatikusak. „A meghatározások és a „fogalmak jelentésének” problémája nem áll közvetlen összefüggésben a historicizmussal. Kimeríthetetlen forrása volt azonban a zűrzavarnak és annak a sza- 
vakkal való zsonglőrködésnek, amely Hegel gondolkodásában összekapcsolódva a historicizmussal kialakította azt a korunkat megfertőző intellektuális rákfenét, amit orákulumszerű filozofálásnak nevezek. Ebben rejlik a forrása annak az Arisztotelésztől eredő, sajnálatos módon még mindig uralkodó szellemi hatásnak, annak a szavakon rágódó, üres skolaszticizmusnak, amely nemcsak a középkorban kísértett, de jelen van saját, kortárs filozófiánkban is" (Popper, 2001, 206.). Teljes érvelését itt nem ismertethetem, ezt lásd Popper 2001, 206-217. o. Kicsit korábban Popper azt az eljárást bírálja, amikor valakinek az a szándéka, hogy egy „felmerülő problémát egy „egészséges és kiegyensúlyozott” ítélet alkalmazásával vigyen nyugvópontra, olyan ítélettel, ami mindenkinek igazságot szolgáltat, ami gyakran csak annyit jelent, hogy tudós és fontoskodó modorban elmegy a lényeg mellett" (Popper 2001, 200. o.).

\section{Irodalom}

Einstein, A. (1971): Az elméleti fizika módszeréről. In: Válogatott tanulmányok, Gondolat, Budapest, 215-226.

Faragó L. (2012): Térértelmezések. Tér és Társadalom, 26., 5-25.

Gatrell, A. C. (1979): Autocorrelation in spaces. Environment and Planning A, 11., 507-516.

Kaplan, A. (1964): The conduct of inquiry: methodology for behavioral science. Chandler, San Francisco Popper, K. R. (2001): A nyitott társadalom és ellenségei. Balassi Kiadó, Budapest 